\title{
Fossils from the Paradisfjeld Group, North Greenland fold belt
}

\author{
John S. Peel and A. K. Higgins

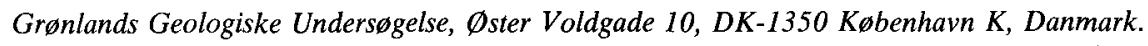

Fossils are recorded for the first time from the Paradisfjeld Group of eastern North Greenland. The Paradisfjeld Group consists of a thick sequence $(c .1000 \mathrm{~m})$ of re-deposited carbonates some of which are of turbiditic origin (Hurst \& Surlyk, 1980; Soper et al. 1980) occurring near the base of the trough sequence exposed in the North Greenland fold belt. Eleven samples collected in 1969 and 1979 by P. R. Dawes, N. J. Soper, J. D. Friderichsen and A. K. H. on the north side of Frederick E. Hyde Fjord, about $10 \mathrm{~km}$ east of Midtkap, were crushed, digested in acetic acid and the dried, sieved residues were density separated in tetrabromoethane. One of the samples, GGU 255639, a calcareous siltstone from the upper part of the sequence, yielded fragmentary phosphatic fossils in the heavy fraction. The scarce fragments include inarticulate brachiopods, curved phosphatic tubes and a broken phosphatic internal mould of a spicule of Chancelloria.

The age of the Paradisfjeld Group has been the subject of some speculation. Dawes \& Soper (1979) suggested a possible age range of Proterozoic to Ordovician. Following the discovery of the present fossils, Hurst \& Surlyk (1980) discount a post-Cambrian age on regional stratigraphic grounds. The occurrence of the fossils clearly indicates that the upper part of the group is of Cambrian or younger Early Palaeozoic age. The presence of Chancelloria suggests a Cambrian age; the distinctive spicules are locally abundant in late Early Cambrian - Middle Cambrian carbonates in the platform sequences of southern Peary Land, immediately to the south of the North Greenland trough. It remains quite possible, however, that the lowest units of the Paradisfjeld Group are of late Proterozoic age, although an earliest Cambrian age should not be discounted.

\section{References}

Dawes, P. R. \& Soper, N. J. 1979: Structural and stratigraphic framework of the North Greenland fold belt in Johannes V. Jensen Land, Peary Land. Rapp. Gronlands geol. Unders. 93, 40 pp.

Hurst, J. M. \& Surlyk, F. 1980: Notes on the Lower Palaeozoic clastic sediments of Peary Land, North Greenland. Rapp. Grønlands geol. Unders. 99, 75-81.

Soper, N. J., Higgins, A. K. \& Friderichsen, J. D. 1980: The North Greenland fold belt in eastern Johannes V. Jensen Land. Rapp. Grønlands geol. Unders. 99, 93-102. 